Available online at GSC Online Press Directory

GSC Biological and Pharmaceutical Sciences

e-ISSN: 2581-3250, CODEN (USA): GBPSC2

Journal homepage: https://www.gsconlinepress.com/journals/gscbps

(RESEARCH ARTICLE)

\title{
In vitro investigation of the antisickling properties of aqueous fruits extracts of Citrus paradisi, Musa acuminata and Malus domestica
}

\author{
Augustine 0. Odibo ${ }^{1}$, Ifunanya R. Akaniro ${ }^{2, *}$ and Emmanuel M. Ubah ${ }^{3}$ \\ ${ }^{1}$ Department of Pharmaceutical Chemistry, Faculty of Pharmacy, University of Benin, Edo State, Nigeria \\ ${ }^{2}$ Department of Microbiology, Faculty of Biological Sciences, University of Nigeria, Enugu State, Nigeria \\ ${ }^{3}$ Department of Microbiology, Faculty of Science, Obafemi Awolowo University, Osun State, Nigeria
}

Publication history: Received on 15 November 2020; revised on 22 December 2020; accepted on 24 December 2020

Article DOI: https://doi.org/10.30574/gscbps.2020.13.3.0412

\begin{abstract}
Sickle cell disease (SCD) is a genetic blood disorder that affects the shape and transportation of red blood cells (RBCs) in blood vessels, leading to various clinical complications. Many drugs that are available for treating the disease are insufficiently effective, toxic, or too expensive. Therefore, there is a pressing need for safe, effective, and inexpensive therapeutic agents from indigenous plants used in ethnomedicine. In the current study, the potentials of aqueous extracts of Citrus paradisi, Musa acuminata, Malusdomestica fruit in sickle cell disease management were investigated in vitro using P-hydroxybenzoic acid and normal saline as positive and negative control respectively. The method employed the inhibition of sodium metabisulphite induced sickling of HbSS red blood cells, collected from confirmed sickle cell patients. Results obtained showed that; $50 \mathrm{mg} / \mathrm{ml}$ aqueous extract of Musa acuminata showed the lowest sickling inhibition (80.3\%) at 60 minutes while $1 \mathrm{mg} / \mathrm{ml}$ gave the highest inhibition of $97.3 \%$ at 90 minutes. For Citrus paradisi, lowest (83.3\%) and highest (98\%) sickling inhibitions were obtained with $25 \mathrm{mg} / \mathrm{ml} \mathrm{and} 50 \mathrm{mg} / \mathrm{ml}$ fruit extracts at 30 minutes and 60 minutes respectively. Malus domestica had the highest antisickling activities of $99 \%$ and $99.33 \%$ respectively at 30 and 60 minutes. In all, the sickling inhibition was least with Musa acuminata but highest with Malus domestica. Also, highest inhibitions were observed at 60 minutes (optimum time) and $10 \mathrm{mg} / \mathrm{ml}$ (optimum concentration). This study has demonstrated that; Malus domestica, Citrus paradisi and Musa acuminata possess antisickling potentials useful in the management or therapy of sickle cell diseases.
\end{abstract}

Keywords: Antioxidants; Ethnomedicine; Hemoglobinopathy; Sickle cell disease; Sickling inhibition

\section{Introduction}

Sickle cell (SC) is a class of hemoglobinopathy caused by mutation in the $\beta$-globin gene in which, the 17 th nucleotide is changed from thymine to adenine and the sixth amino acid in the $\beta$-globin chain becomes valine instead of glutamic acid [1]. The abnormal biochemistry of this mutant haemoglobin induces polymerization of hemoglobin (Hbs) molecules within the red cells, so called sickling. On the sickle haemoglobin, the glutamate protein molecule, which is hydrophilic, polar and negatively charged, is replaced by a less polar, hydrophobic, neutral amino acid, valine. Under deoxy conditions, the abnormal valine residue causes intra-erythrocytic hydrophobic interaction of sickle haemoglobin tetramers, leading to their precipitation and polymer formation, so called gelation [2]. Eventually, all cytosolic haemoglobin molecules precipitate into seven (one inner and six outer) double strands with cross-links which are called tachoids. Upon reoxygenation, unsickling occurs and the red cell assumes its normal shape. However, repeated sickling and unsickling of the red cell damages the red cell membrane, due to herniation of sickle haemoglobin polymers through

${ }^{*}$ Corresponding author: Ifunanya R. Akaniro

Department of Microbiology, Faculty of Biological Sciences, University of Nigeria.

Copyright (C) 2020 Author(s) retain the copyright of this article. This article is published under the terms of the Creative Commons Attribution Liscense 4.0. 
the cytoskeleton, thus rendering the red cell permanently sickled. These appear as irreversibly sickled cells (ISCs) on peripheral blood cytology [3].

According to an epidemiological study carried out by Martinez et al. [4], about 5-7\% of the global population carries an abnormal haemoglobin gene. The most predominant form of haemoglobinopathy worldwide is sickle cell disease and greatest burden of the disease lies in Sub-Saharan Africa and Asia [5]. The gene frequency is highest in West African countries with 1 in 4 or 1 in $3(25-30 \%)$ being carriers of HbS compared to 1 in 400 African Americans or less in European populations [6]. It is estimated that over $80 \%$ of over 300,000 annual births of sickle cell disease (SCD) occur in sub-Saharan Africa (SSA), with the largest burden from Nigeria and Democratic Republic of Congo [5]. Studies have established a link between malaria and SC. The malaria parasite has a complex life cycle and spends part of it in red blood cells. In a carrier, the presence of the malaria parasite causes the red blood cells with defective haemoglobin to rupture prematurely, making the plasmodium parasite unable to produce. Further, the polymerization of $\mathrm{Hb}$ affects the ability of the parasite to digest $\mathrm{Hb}$ in the first place. Therefore, in areas where malaria is a problem, people's chances of survival actually increase if they carry sickle cell trait [7]. SCD is one of the most common inherited life-threatening disorders in humans. Sickle cell diseases commonly result in anaemia and crises which could be of various types; vasoocclusive crises, splenic sequestration crises, aplastic crises, haemolytic crises etc. The vaso-occlusive crises is caused by sickle-shaped red blood cells that obstruct capillaries and restrict blood flow to an organ resulting in ischaemia, pain, necrosis and often organ damage. Splenic sequestration crises are acute, painful enlargements of the spleen, caused by intra-splenic trapping of red cells and resulting in a precipitous fall in haemoglobin levels with the potential for hypovolemic shock. Sequestration crises are considered an emergency. If not treated, patients may die with 1-2 hours due to circulatory failure. These crises are transient, they continue for 3-4 hours and may last for one day [8]. Aplastic crises are acute worsening of the patient's baseline anaemia, producing pale appearance, fast heart rate, and fatigue. This crises is normally triggered by parvovirus B19, which directly affects production of red blood cells by invading the red cell precursors, multiplying in and destroying them. Haemolytic crises are acute accelerated drops in haemoglobin level. The red blood cells break down at a faster rate. This is particularly common in patients with co-existence G6PD deficiency [9].

SCD has been classified into seven (7) according to the abnormality of the haemoglobin molecule. These include: Haemoglobin SS (Sickle cell anaemia), Haemoglobin SC (Sickle cell disease), Haemoglobin S $\beta O$ thalassemia, Haemoglobin S $\beta$ thalassemia, Haemoglobin SD, Haemoglobin SE and Haemoglobin SO Arab disease.

Agents used to prevent or reverse the pathological events leading to sickling of the erythrocytes in sickle cell conditions are called antisickling agents. The use of natural based phytomaterials such as Piper guinensis, Pterocarpus osun, Eugenia caryophylla and Sorghum bicolor extracts as antisickling agents for the treatment of SCD has been reported [10]. Ugbor [11] demonstrated that, the extracts of Pterocarpus santolinoides and Aloe vera were capable of increasing the gelling time of sickle cell blood and inhibit sickling in vivo. Another report indicates that roots of Uvariachamae (Annonaceae) and Plumbagozeylanica (Plumbaginaceae) are part of the constituents that are used in making traditional recipe for the management of sickle cell anaemia [12]. Nurain et al. [13] investigated the antisickling activities of Cajanus cajan leaf and seed, Zanthoxylum zanthoxyloides leaf, and Carica papaya leaf and documented their potentials in the management of SCD. Bamimore and Elujoba [14] also reported the antisickling properties of three commonly used ethnomedicinal plants in Nigeria; Cnestis ferruginea, Alchornea laxiflora and Spathodea campanulata. The present study aims to investigate for the first time, the antisickling properties of aqueous extracts of; Musa acuminate (banana), Citrus Paradisi (grape) and Malus domestica (apple) in vitro. Musa acuminata is a rich source of phytochemicals; tannins, terpenoids, saponins, flavonoids, and phenols [15]. Citrus paradisi contains stilbenes, phenolic acids, anthocyanins and proanthocyanidins [16]. Malus domestica contains procyanidin, epicatechin, uercetin-3-rhamnoside, quercetin-3galactoside, quercetin-3-glucoside, catechin, cyanidin-3-galactoside, chlorogenic acid, phloridzingallic acid and coumaric acid, all of which are strong antioxidants [17]. Studies have demonstrated the potentials of these phytochemicals in ethnomedicinal plants in the treatment of various ailments including sickle cell disease [18-20].

\section{Material and methods}

\subsection{Collection of Plants}

The ripe fruit samples were obtained at the Anatomy Shopping Complex, University of Benin, Benin City on the 28th of March 2020. At the time of collection, the physical conditions of the fruit were good. 


\subsection{Preparation of Extracts}

The fruit samples were weighed individually and washed thoroughly. The epicarps were peeled off and the pulp cut into smaller pieces. The different fruits were transferred separately into the electric blender and blend thoroughly to paste. The blend samples were transferred into a jar of known weight and filtered. The extracts obtained were stored in the fridge at $4^{\circ} \mathrm{C}$ to be used for further analysis.

\subsection{In vitro induction of sickling}

Blood $(5 \mathrm{ml}$ ) was obtained by venipuncture from volunteers confirmed sicklers (HbSS) into sodium EDTA bottle. The bottles were mixed thoroughly by gently rolling the bottle. One drop of blood was mixed with one drop of $2 \%$ sodium metabisulphite solution on a microscope slide with the aid of Fisherbrand pipette. The mixture was gently spread on the slide with the tip of the pipette to make a smear size of a penny, covered with a cover slip and the edge sealed with wax/vaseline mixture. This was then examined under a microscope with the dry objective. The numbers of sickled cells were counted and \% of sickling was calculated by the formula;

$\%$ of sickling $=$ Number of sickled cells $\times 100 /$ Total cells $[21]$.

\subsection{Preparation of Leishman's stain}

The stain used for fixing and staining of the cells was Leishman's stain and was prepared as follows; 0.75 mg of the solid stain was weighed into a mortal and reduced to powder by trituration using a pestle. The powdered stain was dissolved with absolute methanol and quantitatively transferred into a $500 \mathrm{ml}$ volumetric flask and swirled under an incubation temperature of $37^{\circ} \mathrm{C}$ for 30 minutes to aid dissolution and made up to volume with methanol. The stain was stored at room temperature.

\section{Antisickling Test}

\subsection{Preparation of samples for evaluation of antisickling}

Solution of Sodium metabisulphite ( $2 \%$ ) was prepared by dissolving $0.2 \mathrm{~g}$ of sodium metabisulphite in $10 \mathrm{ml}$ of distilled water. Varying concentrations $(1 \mu \mathrm{g} / \mathrm{ml}, 10 \mu \mathrm{g} / \mathrm{ml}, 25 \mu \mathrm{g} / \mathrm{ml}$ and $50 \mu \mathrm{g} / \mathrm{ml})$ of the fruit extracts were prepared by appropriate serial dilution from the stock solution prepared from the freeze dried sample.

\subsection{Procedure for antisickling activity evaluation}

The evaluation of the fruit extracts for antisickling activities was carried out using the modified method of Sofowora et al. [22]. The collected blood samples were centrifuged at $2000 \mathrm{rpm}$ to remove the serum. The resulting packed erythrocytes were washed 3 times with $1 \mathrm{ml}$ sterile normal saline per $5 \mathrm{ml}$ of blood by centrifuging at $2000 \mathrm{rpm}$ each time for 5 minutes. Each time the supernatant was removed, $0.5 \mathrm{ml}$ of the washed erythrocytes was mixed each with $0.5 \mathrm{ml}$ of the different extracts in uncovered test tubes, the samples (extracts-blood mixtures) were incubated at $37^{\circ} \mathrm{C}$ for 3 hours while shaking occasionally. Exactly $0.2 \mathrm{ml}$ of $2 \%$ sodium metabisulphite was added to deoxygenate the system, by gentle rolling of the bottles to mix. Samples were taken in duplicates from the different mixtures at 0 min after which the systems were incubated again at $37^{\circ} \mathrm{C}$ and the samples taken again at 30 minutes interval until 4 readings were obtained. Each sample was smeared on a microscopic slide, fixed with $95 \%$ methanol, dried and stained with Leishman's stain. The slide was examined under the oil immersion objective $(\mathrm{x} 100)$ by counting three fields of approximately 300RBC per field. Biconcave or disk-like shapes were taken to be normal cells while the elongated, starlike, or wrinkled shapes were considered sickled. The numbers of both sickled and unsickled red blood cells were counted and the percentage of unsickled cells determined using the following formula;

(Number of unsickled cells/ total number of counted cells) $\times 100$ [21].

\subsection{Test controls}

Two types of controls were employed in this biological testing. P-hydroxybenzoic acid (PABA-5 mg/ml), a compound known to reverse the sickling HbSS blood cells was used as the positive control. The negative control involves the use of normal saline (N/S). Each set-up in the experiment was replicated thrice. 


\section{Results and discussion}

Table 1 shows the effect of the aqueous extracts of the three fruit extracts in inhibiting red blood cell sickling. Malus domestica had the highest percentage of unsickled red blood cells of $99.33 \%$ at a concentration of $25 \mathrm{mg} / \mathrm{ml}$ at time 0 (T0), $50 \mathrm{mg} / \mathrm{ml}$ at T30 and $10 \mathrm{mg} / \mathrm{ml}$ at T90 while Musa acuminata had the lowest percentage of unsickled red blood cells of $80 \%$ at a concentration of $25 \mathrm{mg} / \mathrm{ml}$ at $\mathrm{T} 60$.

Table 1 Percentage unsickled RBCs obtained with the fruits extracts

\begin{tabular}{|c|c|c|c|c|c|c|c|c|c|c|c|c|c|c|}
\hline \multirow{2}{*}{$\begin{array}{l}\text { Time } \\
\text { (mins) }\end{array}$} & \multicolumn{4}{|c|}{ Musa acuminata } & \multicolumn{4}{|c|}{ Citrus paradisi } & \multicolumn{4}{|c|}{ Malus domestica } & \multicolumn{2}{|c|}{ Control } \\
\hline & 1 & 10 & 25 & 50 & 1 & 10 & 25 & 50 & 1 & 10 & 25 & 50 & $\mathrm{~N} / \mathrm{S}$ & PABA \\
\hline 0 & 96.67 & 98.33 & 83.33 & 88.00 & 96.67 & 93.33 & 93.33 & 96.67 & 90.00 & 95.67 & 93.33 & 96.67 & 60 & 100 \\
\hline 30 & 80.00 & 86.67 & 91.33 & 92.33 & 95.00 & 93.33 & 83.33 & 95.00 & 93.00 & 99.00 & 98.00 & 99.33 & 32 & 100 \\
\hline 60 & 97.33 & 95.67 & 96.00 & 80.00 & 94.00 & 91.67 & 90.67 & 98.00 & 99.33 & 98.00 & 99.33 & 95.00 & 20 & 100 \\
\hline 90 & 83.33 & 90.00 & 98.00 & 85.00 & 98.00 & 98.67 & 97.33 & 95.00 & 98.67 & 99.33 & 97.67 & 96.67 & 15 & 100 \\
\hline Av. & 89.33 & 92.67 & 92.17 & 86.33 & 95.92 & 94.25 & 91.17 & 96.17 & 95.25 & 98.00 & 97.08 & 96.92 & - & - \\
\hline
\end{tabular}

As shown in Fig. 1, P-hydroxybenzoic acid, the positive control demonstrated $100 \%$ sickling inhibition when compared with the aqueous extract of Musa acuminata. Negative control, normal saline showed the highest inhibition of $60 \%$ at time 0 (T0) and lowest inhibition of 15\% at time 90 (T90). This shows there was relatively no inhibition and so majority of the cells still remained sickled after incubation even up to 90 minutes. The highest concentration of Musa acuminata extract $(50 \mathrm{mg} / \mathrm{ml}$ ) showed the second highest inhibition at T30 after P-hydroxybenzoic acid, however, inhibition was not sustained and dropped further up to T60 before another gradual increase was again observed.

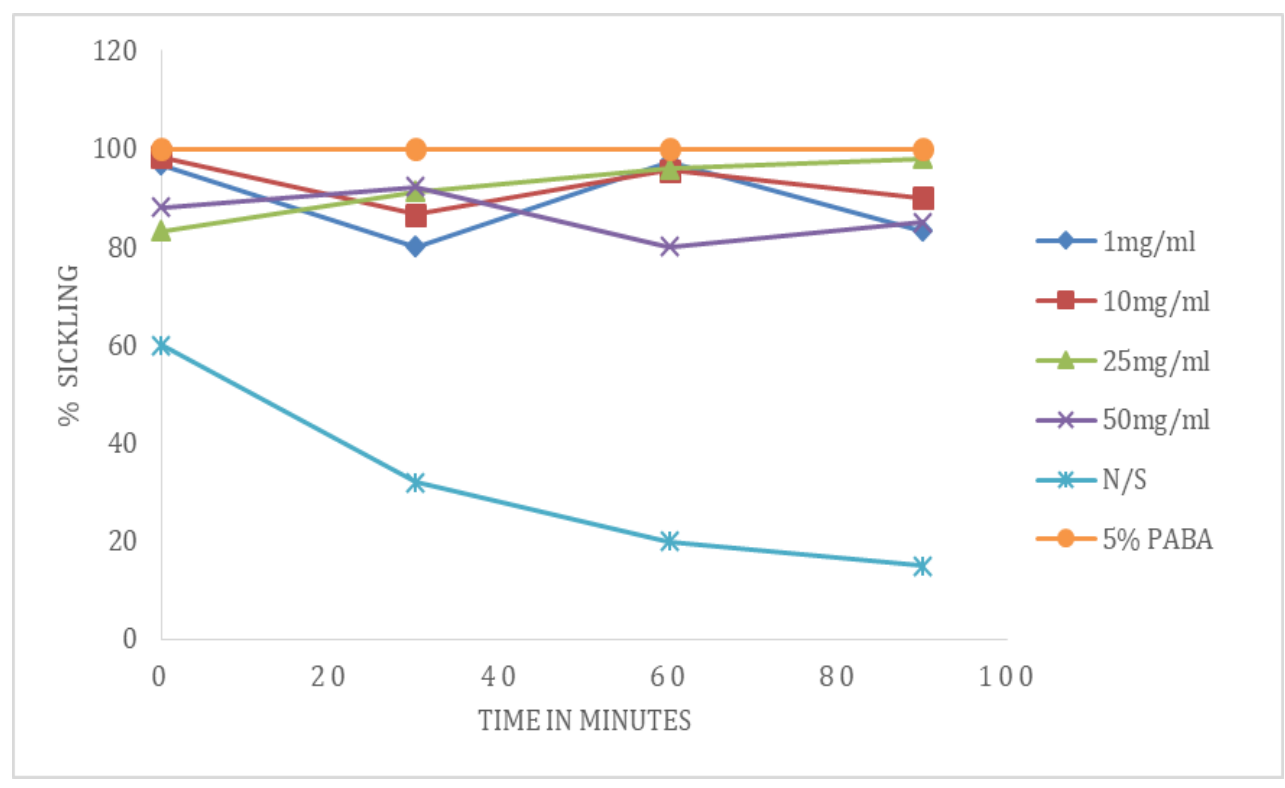

Figure 1 Percentage inhibition of Sickling by aqueous extract of Musa acuminata

Citrus paradisi yielded a more impressive inhibitory potential compared to Musa acuminata. Here, P-hydroxybenzoic acid also demonstrated $100 \%$ sickling inhibition but this was followed closely by $98.7 \%$ sickling inhibition obtained with $10 \mathrm{mg} / \mathrm{ml}$ Citrus paradisi extract (T90) and 98\% inhibition by $50 \mathrm{mg} / \mathrm{ml}$ Citrus paradisi extract (T60). Lowest inhibition obtained for the fruit extracts was $83.3 \%$ at T30 (Fig. 2) 


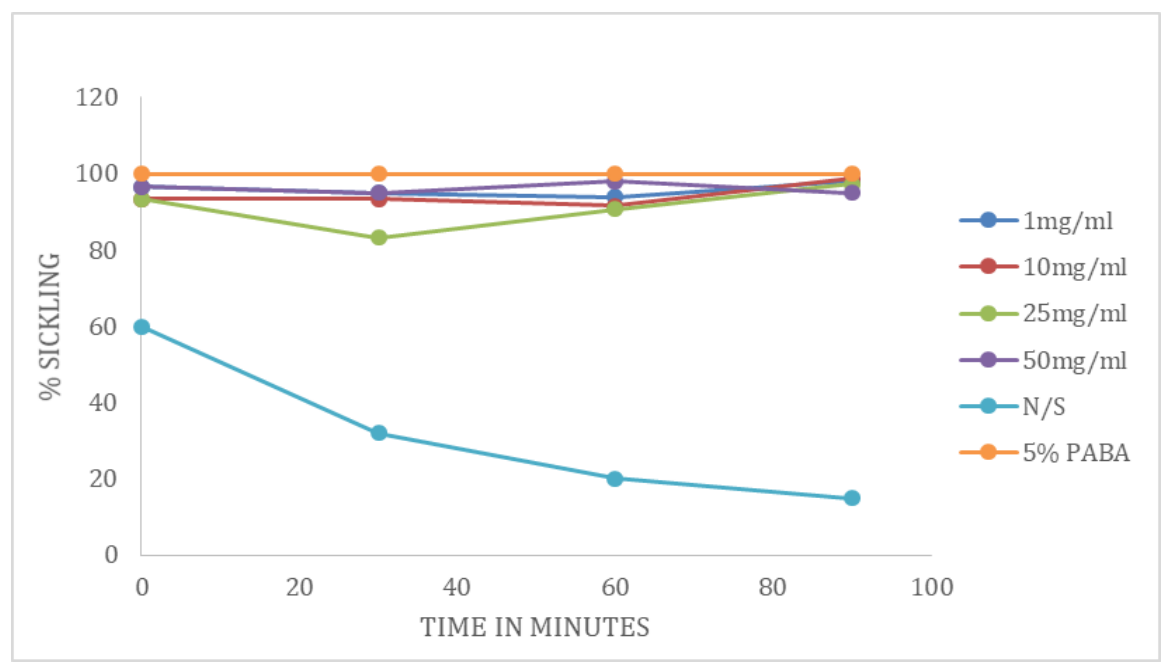

Figure 2 Percentage inhibition of sickling by aqueous extract of Citrus paradise

Malus domestica showed the highest antisickling activity which was sustained even after 90 minutes of incubation of 99.3\% (Fig. 3).

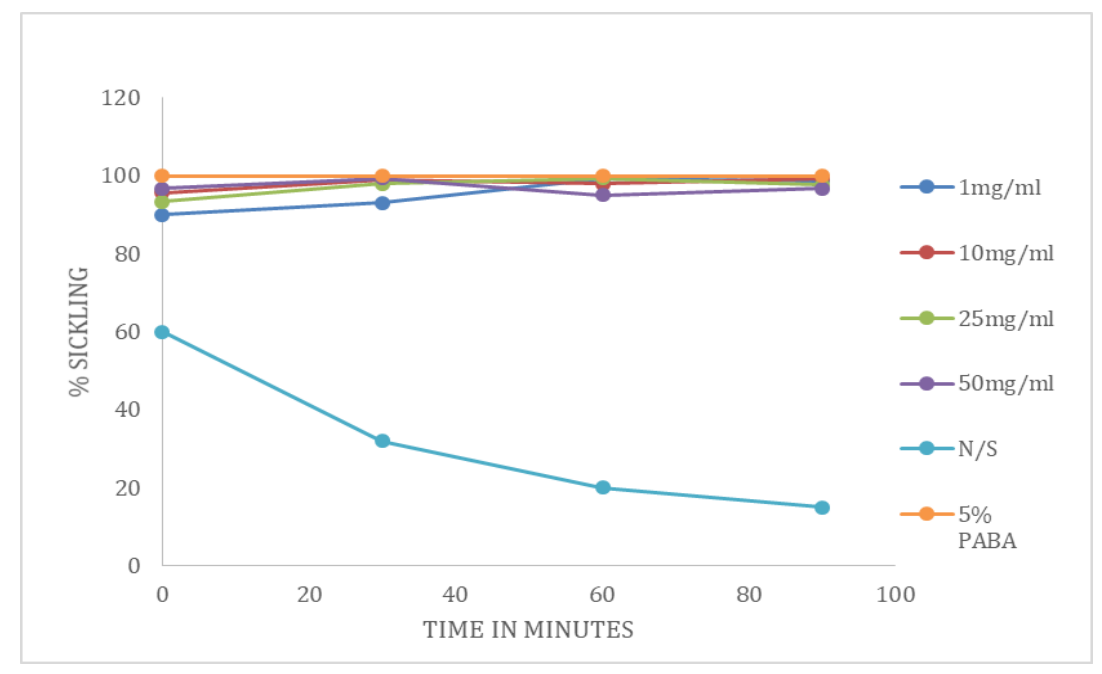

Figure 3 Percentage inhibition of sickling by aqueous extract of Malusdomestica

Sickle cell disease is a serious health concern. There is still a high burden of the disease in Nigeria. Some of the orthodox drugs used in the management of sickle cell disease have been associated with some side effects and as such herbal plants should be considered as alternatives to manage the disease. This study gives a broad overview of some plants investigated for their effects on sickled red blood cells. Results obtained for the antisickling activity of the fruit extracts shows that the extracts exhibited substantial antisickling activity. The aqueous extracts of these fruits showed significant inhibitory effect on sodium metabisulphite induced sickling. Yang and Xiao [16] isolated antioxidants; stilbenes, phenolic acids, anthocyanins and proanthocyanidins from Citrus paradisi. Malus domestica contains procyanidin, epicatechin, uercetin-3-rhamnoside, quercetin-3-galactoside [17]. Also, Anyasi et al. [23] have isolated antioxidant compounds namely: epicatechin and myricetin-3-0-rhamnosyl-glucoside from fruit extracts of Musa acuminata.

Studies have shown the anti-oxidant activity inherent in ethno-medicinal plants are the major components of antisickling, they potentiate this by reducing oxidative stress [24]. Antioxidants are scavengers of free radicals and they help mop up free-radicals produced during sickle cell crisis and thus, help preserve the integrity of the red blood cell membrane [25]. Mpiana et al. [26], Camargo et al. [27] and Nurain et al. [28] have demonstrated that antioxidant molecules are potent inhibitors of sickle haemoglobin polymerization and equally improve the oxidant status of sickle erythrocytes, thus, high oxidative capacity of ethno-medicinal plants are useful in the management of SCD. Plant extracts resulting in influential antisickling activities were also previously reported by other [29-31] 


\section{Conclusion}

Aqueous extracts of the various fruit samples, Musa acuminata, Malus domestica and Citrus paradisi were able to reduce the percentage of sickled cells in vitro. It could be concluded that Musa acuminata, Malus domestica and Citrus paradisi are potential antisickling agents which can be useful for the treatment or management of sickle cell disease. From the results of this investigation, further work need be done on the evaluation of the antisickling activities of the fruit extracts in vivo.

\section{Compliance with ethical standards}

\section{Acknowledgments}

The authors express sincere gratitude to God almighty for His endless blessings and protection upon us and for giving us the grace to complete this research work. Special appreciation to Prof. Abiodun Falodun for his efforts, encouragements, supports and constructive criticism that aided the successful completion of this study. Also, we express special appreciation to Pharm. Vincent Imieje, Dr. Irene and Dr. Ben for their contributions in making this work a success.

\section{Disclosure of conflict of interest}

The authors declare that there is no conflict of interest in this work.

\section{Statement of ethical approval}

The Ethical Clearance protocol for this research was obtained from the hematology unit and submitted to the Ethics and Research Committee (ERC) of the University of Benin Teaching Hospitals Complex.

\section{References}

[1] Piel FB, Steinberg MH, Rees DC. Sickle Cell Disease. The New England Journal of Medicine. Med. 2017; 376: 15611573.

[2] Hoban MD, Orkin SH, Bauer DE. Genetic treatment of a molecular disorder: Gene therapy approaches to sickle cell disease. Blood. 2016; 127: 839-848.

[3] Baba PDI, Lewis LH, Neeraj K, Anissa P, Kilali O, Kofi AA. et al. Sickle Cell Disease-Genetics, Pathophysiology, Clinical Presentation and Treatment. International Journal of Neonatal Screening. 2019; 5(20): 2-15.

[4] Martinez PA, Angastiniotis M, Eleftheriou A, Gulbis B, Pereira MD, Petrova-Benedict R. et al. Haemoglobinopathies in Europe: Health \& migration policy perspectives. Orphanet Journal of Rare Diseases. 2014; 9:97.

[5] Piel FB, Patil AP, Howes RE, Nyangiri OA, Gething PW, Dewi M. et al. Global epidemiology of sickle haemoglobin in neonates: A contemporary geostatistical model-based map and population estimates. Lancet. 2013; 381:142151.

[6] Grosse SD, Odame I, Atrash HK, Amendah DD, Piel FB, Williams TN. Sickle cell disease in Africa: A neglected cause of early childhood mortality. American Journal of Preventive Medicine. 2011; 41: S398-S405.

[7] Mwaiswelo RO, Mawala W, Iversen PO. Sickle cell disease and malaria: decreased exposure and asplenia can modulate the risk from Plasmodium falciparum. Malaria Journal. 2020; 19:165.

[8] Khatib R, Rabah R, Sarnaik SA. The spleen in the sickling disorders; an update.Paediatric Radiology. 2009; 39(1): 17-22.

[9] Balgir RS. Community expansion and gene geography of sickle cell trait and G6PD deficiency, and natural selection against malaria: Experience from tribal land of India, Cardiovascular and Hematological Agents in Medicinal Chemistry. 2012; 10(1): 3-13.

[10] Wambebe C, Khamofu H, Momoh JA, Ekpeyong M, Williams TN, Uyoga S. et al. Bacteraemia in Kenyan children with sickle cell anemia: A retrospective cohort and case control study, Lancet. 2009; 274: 1364-1370. 
[11] Ugbor C. The effect of vegetable extracts on the antisickling potential of Aloe vera.

[12] Egunyomi A, Moody JO, Eletu OM. Antisickling activities of two rthnomedicinal plant recipes used for the management of sickle cell anemia in Ibadan, Nigeria. African Journal Biotechnology. 2009; 8: 20-256.

[13] Nurain IO, Bewaji CO, Johnson SJ, Davenport RD, Zhang Y. Potential of Three Ethnomedicinal Plants as Antisickling Agents . Molecular Pharmaceutics.

[14] Bamimore VO, Elujoba, AA. Antisickling Properties of Three Medicinal Plants and Their Combinations. International Journal of Pharmacognosy. 2018; 5(10): 666-672.

[15] Aina 00, Oyedeji MB, Adegboyega DA, Owoloja AO. Phytochemical screening of some selected banana peels of Musa acuminata specie. International Journal of Agriculture, Environment and Bioresearch.2019; 4(6): 68-78.

[16] Yang J, Xiao Y. Grape phytochemicals and associated health benefits. Critical Reviews in Food Science and Nutrition. 2013; 53(11): 1202-1205.

[17] Avrin RL, Satish S, Shabaraya AR. Review on pharmacological activties of MalusDomestica. International Journal of Pharma and Chemical Research. 2018; 4(4):243-247.

[18] Mpiana PT, Mudogo V, Tshibangu DST. Antisickling activity of anthocyanins from B. pentadrum, F. capensis, E. hirta and Ziziphusmucronata: Photodegradation effect. Journal of Ethnopharmacology. 2008; 120(3): $413-418$.

[19] Adejumo OE, Owa-Agbanah IS, Kolapo AL. Phytochemical and anti-sickling activities of Entandrophragma utile, Chenopodiumambrosiodes and petiveriaalliacea. Journal of Medicinal Plant Research. 2011; 5:1531-1535.

[20] Vaisnava S, Rangari VD. A review on phytochemical and pharmacological research-Remedy for sickle cell disease. International Journal of Pharmaceutical Sciences and Research. 2016; 4: 472-481.

[21] Pauline N, Cabral BNP, Anatole PC, Jocelyne AMV, Bruno M, Jeanne NY. The in vitro antisickling and antioxidant effects of aqueous extracts Zanthoxyllumheitzii. Biomed Central. 2013; 13: 1-7.

[22] Sofowora EA, Isaac-Sodeye WA. Reversal of sickling and crenation in erythrocytes by the root of Fagaraxanthoxyloides. Lioydia. 1971; 34: 383.

[23] Anyasi TA, Jideani AIO, Mchau GRA. (2018). Phenolics and essential mineral profiles of organic acid pretreated unripe banana flour. Food Research International (Ottawa Ontario). 104: 100-109.

[24] Imaga NA. Phytomedicines and nutraceuticals: alternative therapeutics for sickle cell anemia. Science World Journal. 2013: 1-12.

[25] Azubuike CP, Uzoeto CA, Igbokwe NH, Igwilo CI. In vitro antisickling, antimicrobial and antioxidant potentials of extracts of Sorghum bicolor (L) moench seeds and Mangiferaindica (L) anacardiaceae leaves and their formulations. Journal of Pharmacy Practice and Pharmaceutical Sciences. 2016; 3: 135-144.

[26] Mpiana PT, Lombe BK, Ombeni AM, Ngbolua K, Tshibangu DST, Wimba LK. et al. In vitro sickling inhibitory effects and anti-sickle erythrocytes hemolysis of Diclipteracolorata C. B. clarke, Euphorbia hirta L. and Sorghum bicolor (L.). Open Journal of Blood Disorders. 2013; 3: 43-48.

[27] Camargo LEA, Pedroso LS, Vendram SC, Mainardes RM, Khalil NM. Antioxidant and antifungal activities of Camellia sinensis (L.) kuntze leaves obtained by different forms of production. Brazilian Journal of Biology. 2016; 76: 428-4.

[28] Nurain IO, Clement OB, Johnson JS, Davenport RD, Zhang Y. Potential of three ethnomedicinal plants as antisickling agents. Molecular Pharmaceutics. 2017; 14: 172-182.

[29] Dash BP, Archana Y, Satapathy N, Naik SK. Search for antisickling agents from plants. Pharmacognosy Reviews. 2013; 7: 53-60.

[30] Mishra PK, Sharma S, Jain V, Tiwara J, Mishra M, Patra PK and Khodiar PK. Antisickling and antioxidant relevance of twelve ethnomedicinal plants. Medicinal Plants. 2018; 10(3): 226-235.

[31] Onyegeme-Okerenta BM, Essien EB, Esin JI. Anti-sickling Properties of Aqueous Extracts of Dennettiatripetala and Physalisangulata. Asian Journal of Biological Sciences. 2019; 12(4): 772-778. 